\title{
Fruit yield and quality of the grafted tomatoes under different drought stress conditions
}

\author{
Sepideh Kazemi ${ }^{1}$, Abdolrasool Zakerin², Vahid Abdossi ${ }^{3}$, Pezhman Moradi ${ }^{4}$ \\ ${ }^{1}$ Ph.D student, Department of Horticultural Science and Agronomy, Science and Research Branch, Islamic Azad University, \\ Tehran, Iran. \\ ${ }^{2}$ Assistant Professor, Department of Horticultural Science, Jahrom Branch, Islamic Azad University, Jahrom, Iran. \\ ${ }^{3}$ Assistant Professor, Department of Horticultural Science and Agronomy, Science and Research Branch, Islamic Azad \\ University, Tehran, Iran. \\ ${ }^{4}$ Associate Professor, Department of Horticultural Science, Saveh Branch, Islamic Azad University, Saveh, Iran.
}

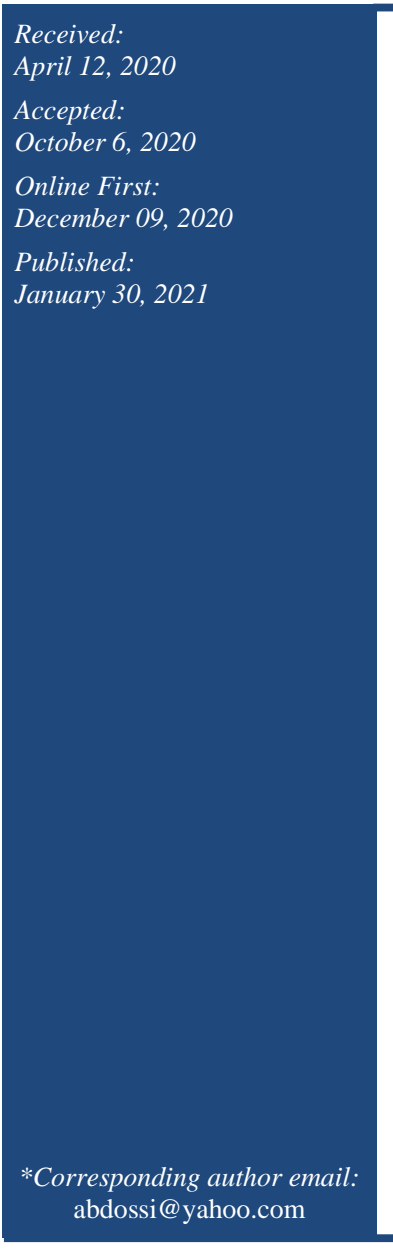

\begin{abstract}
This study was evaluated the effect of different rootstocks, scion, and drought stress levels on yield, yield components and biochemical characteristics of four commercial tomato cultivars. In this regard, the combinations of three rootstocks (Dashtestan, Dorahe, and Mond) and four scions (Ra'ad, Matine, Super chief, and Rockstone) were investigated under three drought stress treatments, including 50, 75 and $100 \%$ water requirement. After grafting, grafting success rate (percent) and some vegetative and reproductive parameters were measured. Considering the main effect of rootstock, the highest percentage of success in grafting unit (up to 50\%) was obtained by the Dashtestan rootstock, while the lowest (40\%) was obtained by the Mond rootstock. The results showed that drought stress and different rootstocks had significant effects on plant height $(\mathrm{p}<0.05)$, average fruit weight, flower and fruit numbers, protein and lycopene contents $(\mathrm{p}<0.01)$. On the other hand, there were significant interactions between drought stress, rootstock and scion in respect of average fruit weight, flower and fruit number, TSS, firmness, protein, lycopene, and superoxide dismutase(SOD). So that, in the conditions of the experiment, drought stress caused an increase in some parameters such as fruit TSS and firmness, the contents of carotenoids, flower number, protein content and activities of catalase(CAT), peroxidase, and superoxide dismutase enzymes. It could be concluded that the best combinations of rootstock and scion were Ra'ad and Super Chief scions, respectively on Dashtestan rootstock. So that, in many evaluated parameters these rootstock-scion combinations were better than others.
\end{abstract}

Keywords: Cleft grafting, Gillette razor, Rootstock, Scion, Tomato

How to cite this:

Kazemi S, Zakerin A, Abdossi V and Moradi P, 2021. Fruit yield and quality of the grafted tomatoes under different drought stress conditions. Asian J. Agric. Biol. 2021(1). DOI: https://doi.org/10.35495/ajab.2020.03.164

This is an Open Access article distributed under the terms of the Creative Commons Attribution 3.0 License. (https://creativecommons.org/licenses/by/3.0), which permits unrestricted use, distribution, and reproduction in any medium, provided the original work is properly cited.

\section{Introduction}

The act of grafting involves the vegetative parts of two individual plants to join into one through the fusion process. The two plants would join are referred to as the rootstock and the scion thereafter. The rootstock is responsible for providing the plant with water and nutrients through its root system after grafting, while 
the scion forms the aerial parts of the plant where the crop grows and is harvested. The methods of grafting herbaceous plants such as vegetables and field crops are quite different from those of woody species. Furthermore, there are various methods of grafting for different species of herbaceous plants, and the methods may even differ within similar species (Maria, 2015). Grafting can be performed as an approach to increase the resistance of tomato cultivars to drought. One of the techniques that can be used against drought stress is the grafting of seedlings before their transfer to greenhouse conditions. The method is used not only to induce tolerance to drought but also to create resistance against diseases and low temperatures. In some studies, the quality of tomato has been characterized by Brix $\left(^{\circ}\right)$, acidity, and lycopene content, which were not affected by grafting. Tomato color, like the color of many other fruits, is an essential feature derived from the carotenoids $\beta$ and $\alpha$. Carotenoid pigments are responsible for the color of tomatoes. Increasing the drought tolerance in the grafted rootstocks of tomato corresponds with the ability of roots to prevent the movement of sodium and chloride ions toward the shoots and aerial parts of plants (Estan et al., 2005). Shahabi (2011) examined the effects of different methods of grafting on the growth and yield of tomato "Red Top" by grafting techniques on vegetables and field crops. The results showed that grafting annual plants contributed to reducing the occurrence of damages caused by soil diseases and pests. Moreover, it was observed that grafting increases the resistance of plants against several types of stress (i.e. salinity, drought, and low temperatures) as well as increasing the vegetative growth and the absorption of nutrients, which lead to higher yields.

In this research, the aim of grafting cultivar scions onto wild-type rootstocks was to produce a plant that can tolerate drought stress and be resistant against various diseases during the developmental stages of the grafted transplants. Martin et al. (2002) reported that the soluble salts were transferred from rootstocks to scions in vegetable and field crops, while at the same time the permanent changes occur to the tolerance threshold of scion against salinity that is due to the mechanisms for transferring the soluble materials. A report by Fernandez-Garcia et al. (2002) showed that grafting the tomatoes onto the appropriate rootstock could increase the yield of the product as well as fruit quality. In the mentioned study, commercial rootstocks were used for tomato grafting.
Chachalis et al. (2006) experimented with grafting the tomatoes and observed the effects on plants under both greenhouse conditions and the open field. However, the results of the experiment showed that the grafted plants yielded lower amounts of produce under both conditions of the greenhouse and open field. Early ripening was also observed in the yield of fruits.

\section{Material and Methods}

In this research, the effects of grafting the scions onto wild-type rootstocks were examined on the resistance to drought stress. The scions were obtained from four new cultivars ("Matine", "Ra'ad", "Rockstone" and "Super Chief") and the rootstocks were from three wild-type cultivars of tomatoes ("Dorahe", "Dashtestan" and "Mond"). Cleft grafting was performed two weeks after germination and seedling emergence of rootstocks. The nutrient regime of all grafted transplants in this research was supplied with equal and adequate amounts of fertilizer. During the experiment, it was endeavored to counter pests and any possible disease, along with the provision of optimal growth conditions and common agronomic management. The treatments of drought stress consisted of 100, 75 and $50 \%$ water requirement that were used at the beginning of the flowering stage. The $100 \%$ water requirement was estimated every day using evapo-transpiration data. Irrigation was performed once a day. The factors, which were measured in the study, included the time of flowering induction and that of fruit set after the grafting, and the percentage of grafting success rate (\%). The experiment had three replications, each of which contained four plants. There were 432 grafted plants. The evaluated parameters were day to flowering and fruit set, plant height, average fruit weight, $\mathrm{pH}$ of fruit juice, fruit and flower numbers, the content of vitamin C, TSS, protein content, total yield, fruit firmness, lycopene content, the contents of carotenoids, chlorophyll content, MDA content, the activities of SOD, CAT and peroxidase. Fruit weight and $\mathrm{pH}$ of fruit juice were measured by the digital scale and $\mathrm{pH}$ meter model Horiba, respectively. The amount of vitamin $\mathrm{C}$ was evaluated using titration with the iodine in potassium iodide. TSS was assayed using a manual refractometer. To measure protein content, the samples were digested according to the Microkjeldahl method. After the titration stage, the protein content was calculated using the conversion coefficient: $\mathrm{N} \times$ 
6.25 (Bradford, 1976). By measuring the density of light by spectrophotometer in $503 \mathrm{~nm}$ wavelength according to the method of Fish et al. (2002), the amount of lycopene in $\mathrm{mg} / 100$ grams of pulp was calculated using the formula as follows:

$$
\text { Lycopene }(\mathrm{mg} / \mathrm{kg} \text { tissue })=\frac{A_{503} \times 31.2}{g \text { tissue }}
$$

The activity of the catalase enzyme (Dhindsa and Motowe, 1981) was measured with a spectrophotometer device at wavelength (240) $\mathrm{nm}$ in 30 seconds. In addition, sodium phosphate buffer $(20 \mathrm{mM})$ with $30 \%$ was used as an electron receptor $\left(\mathrm{H}_{2} \mathrm{O}_{7}\right)$ and $20 \mu \mathrm{l}$ of hydrogen peroxide. The activity of catalase is expressed in terms of unit per milligram of protein. To study the activity of the peroxidase enzyme, leaf protein was extracted (Agrawal et al., 2011). To evaluate the activity of peroxidase enzyme (Ec: 1.11.1.13), the reaction mixture consists of 10 $\mathrm{mM}$ phosphorus, $8 \mathrm{mM}, 2.5 \mathrm{mM}$ hydrogen peroxide, and 50 moles of protein solution extracted from the above. After adding hydrogen peroxide, immediately increasing the absorbance at $470 \mathrm{~nm}$ for 60 seconds will be read. The specific activity of the enzyme will be expressed as micromolar tetragioclone per minute expressed in $\mathrm{mg}$ of protein (Plewa et al., 1991). To determine the concentration of malondialdehyde in the leaves, a half one gram of fresh leaves was completely powdered in a solution of $20 \%$ Thiocchrocetic Acid (TCA) containing $0.5 \%$ barbituric acid, and then mixed and heated at $95{ }^{\circ} \mathrm{C}$ for 25 minutes at in the Bain-marie. The mixture was then cooled in an ice bath and, according to (Valantovic et al., 2006) the concentration of malondialdehyde at $523 \mathrm{~nm}$ was measured. The activity of SOD was evaluated according to the method by Giannopolitis and Ries (1997).

To measure the contents of chlorophyll and carotenoids, 0.5 gram of leaf was grounded in mortar and pestle and then crushed with liquid nitrogen. $20 \mathrm{ml}$ of $80 \%$ acetone was added to the sample and then centrifuged at $6000 \mathrm{rpm}, 10 \mathrm{mins}$. The extracts were assayed with a spectrophotometer at $663 \mathrm{~nm}$ for chlorophyll a and $645 \mathrm{~nm}$ for chlorophyll $\mathrm{b}$ and 470 $\mathrm{nm}$ for carotenoids. Finally, using the following formulas, the amount of chlorophyll a, b and carotenoids in $\mathrm{mg} / \mathrm{g}$ of fresh weight were calculated (Arnon, 1956):

$$
\begin{aligned}
& \text { Chlorophyll } \mathrm{a}=(19.3 \times \mathrm{A} 645-3.6 \times \mathrm{A} 663)=\frac{\mathrm{V}}{100 \mathrm{~W}} \\
& \text { Chlorophyll } \mathrm{b}=(19.3 \times \mathrm{A} 645-3.6 \times \mathrm{A} 663)=\frac{\mathrm{V}}{100 \mathrm{~W}} \\
& \text { Carotenoides }=\frac{100(\mathrm{~A} 470)-3.27(\mathrm{mg} \text { chl. } \mathrm{a})-104(\mathrm{mgchl} . \mathrm{b})}{227}
\end{aligned}
$$

The statistical design used in the research was a completely randomized design. The analysis of variance was performed using SAS 9.1 software and the means were compared with the LSD test at $p<0.05$. The figures were drawn with Excel.

\section{Results and Discussion}

The results of the variance analysis showed that drought stress had a significant influence on some traits such as plant height $(\mathrm{p}<0.05)$, average fruit weight, flower and fruit numbers, the contents of protein and lycopene and the activity of SOD $(p<0.01)$. The main effect of rootstock was significant on some traits, including the content of vitamin $\mathrm{C}$, the activities of catalase and peroxidase $(\mathrm{p}<0.05)$, average fruit weight, flower and fruit numbers, the contents of lycopene, chlorophyll, and SOD activity $(\mathrm{p}<0.01)$. The main effect of scion was significant in some parameters, including day to fruit set $(\mathrm{p}<0.05)$, day to flowering, average fruit weight, flower and fruit numbers, protein content, the activities of peroxidase and SOD $(\mathrm{p}<0.01)$. There was a significant interaction between drought stress and rootstock in respect of some parameters, including average fruit weight, flower and fruit numbers, TSS, firmness, the contents of protein and lycopene and SOD activity. Interaction between drought stress and scion was significant in the parameters of plant height, average fruit weight, flower and fruit numbers, TSS, the contents of protein, lycopene, and carotenoids, the activities of catalase, peroxidase and SOD. 
Sepideh Kazemi et al.

Table-1. Results of analysis of variance (ANOVA) of drought (D), rootstock (R) and scion (S) effects and their interactions for the dependent variables considered

\begin{tabular}{|l|c|c|c|c|c|c|c|c|}
\hline \multirow{2}{*}{ Dependent variable } & \multicolumn{7}{|c|}{ Independent variable } \\
\cline { 2 - 9 } & $\mathrm{D}$ & $\mathrm{R}$ & $\mathrm{S}$ & $\mathrm{D} \times \mathrm{R}$ & $\mathrm{D} \times \mathrm{S}$ & $\mathrm{R} \times \mathrm{S}$ & $\mathrm{D} \times \mathrm{R} \times \mathrm{S}$ & $\mathrm{C} . \mathrm{V} \%$ \\
\hline Day to flowering & $\dagger 1.59$ & 4.23 & $12.85^{* *}$ & 4.63 & 2.04 & $8.90^{* *}$ & 1.88 & 4.6 \\
\hline Day to fruit set & 2.37 & 2.93 & $4.28^{*}$ & 0.93 & 0.69 & $7.32^{* *}$ & 0.28 & 2.0 \\
\hline Plant height & $337.2^{*}$ & 182.4 & 39.0 & 131.8 & $430.9^{* *}$ & 129.7 & $327.8^{* *}$ & 18.8 \\
\hline Average fruit weight & $2047^{* *}$ & $6009^{* *}$ & $4936^{* *}$ & $3881^{* *}$ & $3981^{* *}$ & $987^{* *}$ & $1452^{* *}$ & 11.1 \\
\hline Flower number & $121.9^{* *}$ & $27.0^{* *}$ & $92.5^{* *}$ & $115.8^{* *}$ & $55.5^{* *}$ & $47.3^{* *}$ & $91.9^{* *}$ & 13.3 \\
\hline Fruit number & $24.5^{* *}$ & $12.5^{* *}$ & $21.9^{* *}$ & $41.6^{* *}$ & $18.5^{* *}$ & $15.1^{* *}$ & $23.1^{* *}$ & 16.8 \\
\hline Fruit juice pH & 0.21 & 0.47 & 0.11 & 0.08 & 0.08 & 0.34 & 0.23 & 8.5 \\
\hline Vitamin C & 0.34 & $2.19^{*}$ & 0.52 & 1.04 & 0.96 & 0.48 & 0.73 & 13.3 \\
\hline TSS & 0.34 & 0.18 & 0.90 & $2.73^{*}$ & $3.54^{* *}$ & 0.89 & 1.34 & 16.9 \\
\hline Firmness & 0.28 & 0.08 & 0.12 & $0.65^{* *}$ & 0.14 & $0.38^{*}$ & 0.22 & 20.2 \\
\hline Protein & $48.0^{* *}$ & 1.7 & $77.2^{* *}$ & $20.6^{* *}$ & $68.7^{* *}$ & $86.5^{* *}$ & $40.3^{* *}$ & 4.3 \\
\hline Lycopene & $22.6^{* *}$ & $9.6^{* *}$ & 0.2 & $29.3^{* *}$ & $20.1^{* *}$ & $5.6^{* *}$ & $12.1^{* *}$ & 2.7 \\
\hline Chlorophyll & 21.6 & $153.0^{* *}$ & 18.0 & 73.1 & 67.47 & 17.9 & $73.3^{*}$ & 11.7 \\
\hline Carotenoid & 0.04 & 0.12 & 0.15 & 0.12 & $0.22^{*}$ & 0.14 & 0.11 & 9.1 \\
\hline Catalase & 4.1 & $9.6^{* *}$ & 4.5 & 3.5 & $6.3^{*}$ & 2.4 & $7.0^{* *}$ & 4.1 \\
\hline Peroxidase & 0.85 & $9.6^{*}$ & $6.21^{* *}$ & 2.94 & $4.23^{* *}$ & $3.14^{*}$ & $7.41^{* *}$ & 5.1 \\
\hline SOD & $11.7^{* *}$ & $7.6^{* *}$ & $34.3^{* *}$ & $10.2^{* *}$ & $10.3^{* *}$ & $6.0^{* *}$ & $13.4^{* *}$ & 4.5 \\
\hline MDA & 0.02 & 0.03 & 0.10 & 0.03 & 0.07 & 0.01 & 0.05 & 7.5 \\
\hline Total yield & 3.1 & 11.4 & 2.8 & 5.6 & 5.9 & $9.9^{*}$ & 3.4 & 4.0 \\
\hline
\end{tabular}

†Mean square, $* \mathrm{p}<0.05, * * \mathrm{p}<0.01$.

There was a significant interaction between rootstock and scion about day to flowering and fruit set, average fruit weight, flower and fruit numbers, firmness, the contents of protein and lycopene, the activities of peroxidase and SOD, and total yield. Interactions among three factors of drought stress, rootstock and scion were significant in respect of the parameters such as plant height, average fruit weight, flower and fruit numbers, the contents of protein, lycopene, and chlorophyll, the activities of catalase, peroxidase, and SOD (Table 1).

\section{Fruit quality}

The highest vitamin $\mathrm{C}$ of the fruits was observed in the Dashtestan rootstock, which had a significant difference with the Dorahe rootstock. In this relation, there was no significant difference between the Mond rootstock and the two others (Fig. 1). This result was not in conformity with the findings by Pouzesh-shirazi et al. (2013), because they did not find any significant difference among the assessed rootstocks in viewpoint of the parameters such as total acid, vitamin $\mathrm{C}$ and plant weight.

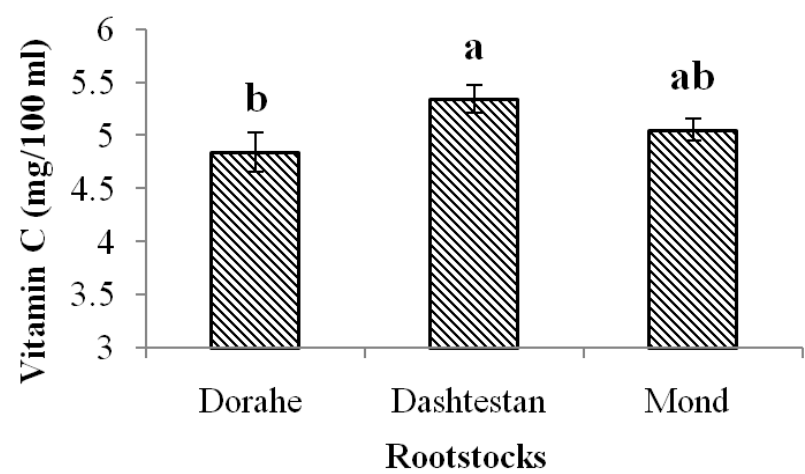

Figure-1. Amount of vitamin $\mathrm{C}$ as influenced by single effect of rootstock

The TSS value increased with the reduction of the used water in the three rootstocks. In the Mond rootstock, increasing TSS by intensifying the drought stress from 100 to $75 \%$ water requirement was more gradually than two other rootstocks. In contrast, increasing of TSS by intensifying the drought stress from 75 to $50 \%$ water requirement in the Dashtestan rootstock was more gradually than the Mond rootstock, so that the increasing of TSS in Dashtestan rootstock was slower than Mond rootstock. An increase in the TSS by intensifying the water stress in the Dorahe rootstock 
ascended (Fig. 2A). The findings reported by Pouzeshshirazi et al. (2013) were similar to our results. The changing trend of fruit firmness ascended in three rootstocks with a reduction of the used water, so that fruit firmness slowly increased from 100 to $75 \%$ water requirement (WRq), however, from 75 to $50 \% \mathrm{WRq}$ the enhancement was rather. The fruits on the Mond rootstock were more firm than two other rootstocks in the highest level of drought stress (Fig. 2B).

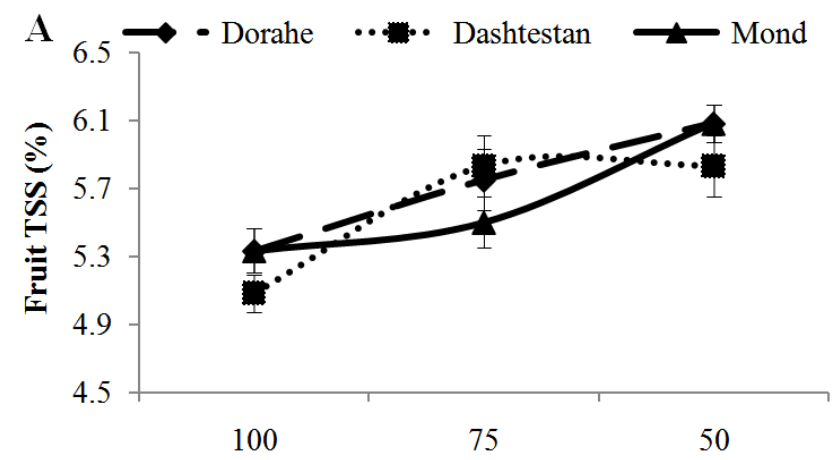

Drought stress (\% water requirment)

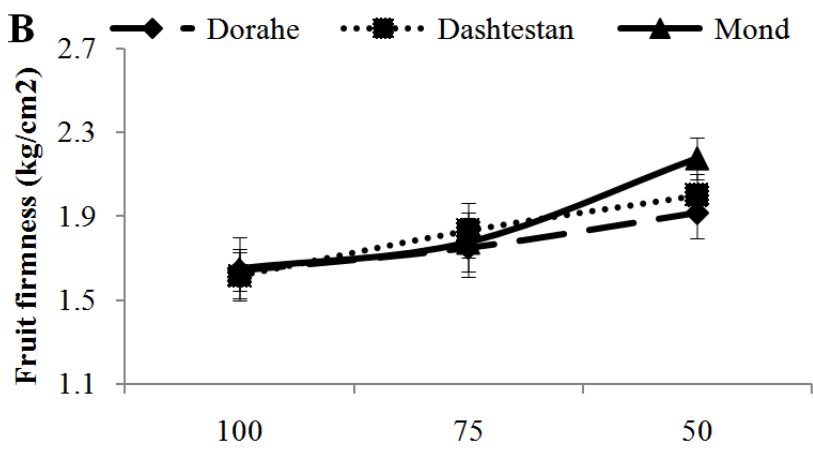

Drought stress (\% water requirment)

Figure-2. Fruit TSS (A) and firmness (B) as influenced by interaction between drought stress and rootstock

According to Fig 2B, by increasing the water stress, the fruit firmness was increased. Similar to our results, Maria (2015) found that in three tomato cultivars, fruit firmness was significantly improved in the absence of irrigation. According to Guichard et al. (2011), the positive effect of water stress may be associated with a decrease in internal firmness of the fruit, which could lead to lower pressure on the cell walls and thus the greater epidermal elasticity possibly compensated by strengthening of the cell walls. These results are in agreement with those previously reported for tomato by other authors (Sofo et al., 2004).

The TSS is among effective parameters in qualitative properties of tomato that its amount depends on the genotype and plant growth conditions. The higher TSS leads to increase fruit nutrition value for the processing industries and it will have better processability (Owen and Aung, 1990). In the present study, the TSS increased when the drought stress intensified (Fig. 3A), so that fruit TSS of the Super Chief scion increased with a more gentle gradient than others, which is according to the findings reported by Ashraf and Harris (2005), so that the changes due to salinity stress in the findings of them were in direction with the our results. Furthermore, increasing the drought stress caused an increase in the contents of carotenoids (Fig. 3B), so that the enhancement of carotenoids in the fruits of Super Chief and Matine scions were observed with lower gradient. These results are following the findings of other researches on tomato (Maria, 2015; Veit-Kohler et al., 1999; Naotke et al., 1998; Matsuzoe et al., 1998; Riggi et al., 2008).

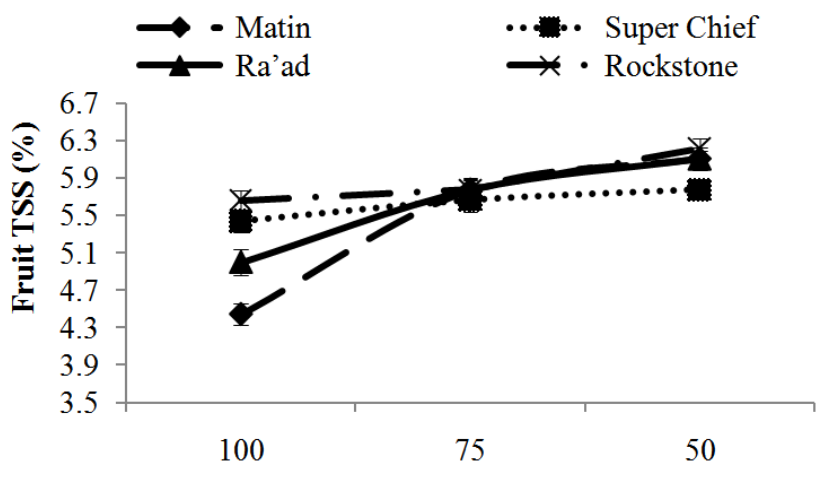

Drought stress (\% water requirment)

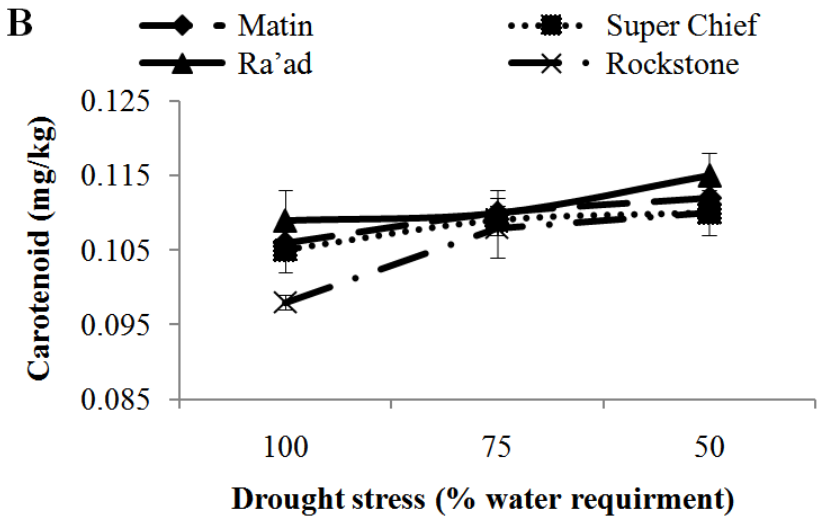

Figure-3. Fruit TSS (A) and carotenoid content (B) as influenced by interaction between drought stress and scion 

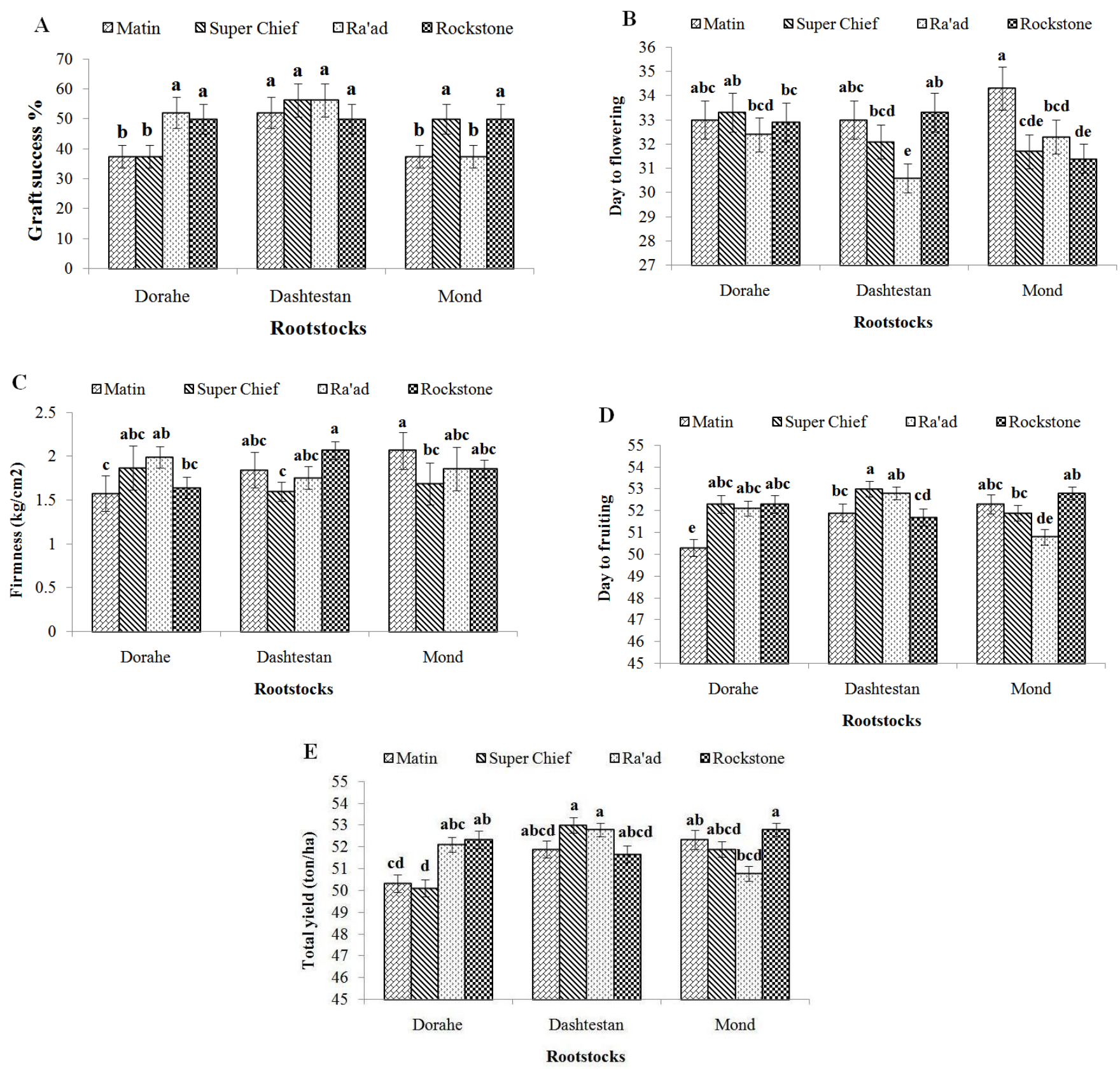

Figure-4. Graft success percentage (A), day to flowering (B), firmness (C), day to fruiting (D), total yield (E) as influenced by interaction between rootstock and scion

\section{Plant growth and development}

All four scions had the highest grafting success rate $(\% ; \mathrm{GS} \%)$ on the Dashtestan rootstock. The Ra'ad and Rockstone scions had the greatest GS\% on the Dorahe rootstock. Likewise, the Super Chief and Rockstone scions had the highest GS\% on the Mond rootstock. The lowest GS\% was observed in Matine and Super Chief scions onto Dorahe rootstock as well as in Super Chief and Ra'ad scions on Mond rootstock (Fig.
4A).The scion of Matine grafted onto Dorahe rootstock reduced day to fruit set compared to other scion-rootstock combinations, though this scionrootstock combination had no significant difference in fruit set compared with Ra'ad scion onto Mond rootstock. The longest day to fruit set was recorded in the scion of Super Chief cultivar onto Dashtestan rootstock that it had no significant difference with many other scion-rootstock combinations (Fig. 4D). 
The highest fruit yield obtained from Super Chief and Ra'ad scions onto Dashtestan rootstock as well as Rockstone scion onto Mond rootstock. The lowest total fruit yield was observed in Super Chief and Matine scions onto Dorahe rootstock. The fruit yields of four scions onto Dashtestan rootstock were more than others (Fig. 4E).

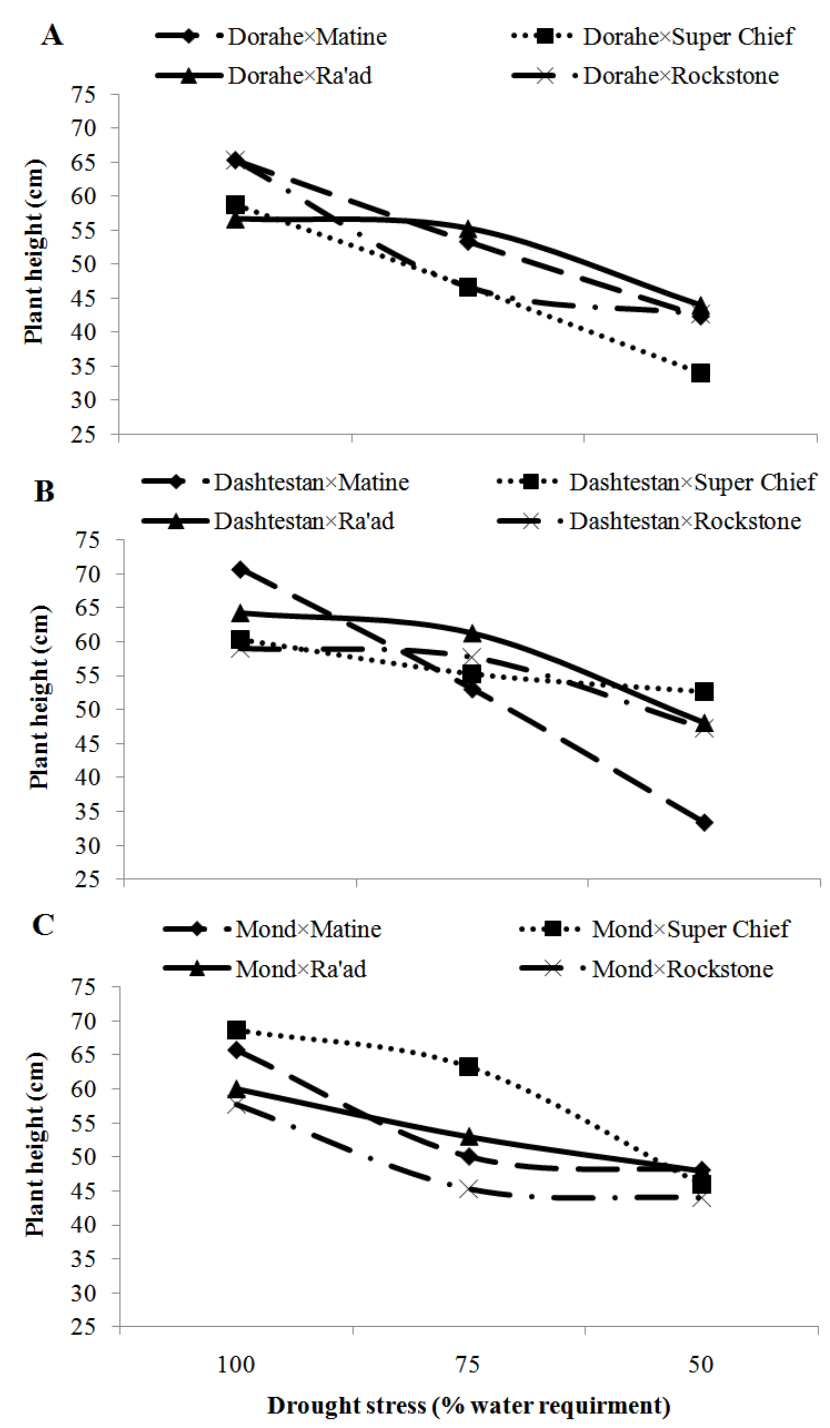

Figure-5. Plant height as influenced by interaction among drought strees, scion and each rootstocks of Dorahe (A), Dashtestan (B) and Mond (C)

Generally, plant height decreased when drought stress levels were intensified in all scion-rootstock combinations so that concerning the Dorahe rootstock, drought stress affected the plant height of Super Chief scion more than other scions onto this rootstock. The control of plant height influenced by drought stress was higher in Ra'ad scion onto Dorahe rootstock. Based on the Fig. 5A the change of the plant height with increasing water stress in $\mathrm{Ra}$ 'ad $\times$ Dorahe combination was lower than others (Fig. 5A). In respect of the Dashtestan rootstock, drought stress affected the plant height of Matine scion more than other scions onto this rootstock. The control of plant height influenced by drought stress was higher in Super Chief scion onto Dashtestan rootstock. Based on the Fig. 5B the change of plant height with increasing water stress in Super Chief $\times$ Dashtestan combination was lower than others (Fig. 5B).

In the Mond rootstock, drought stress affected the plant height of Super Chief scion more than other scions onto this rootstock. The control of plant height influenced by drought stress was higher in Ra'ad scion onto Mond rootstock. Based on the Fig. 5C the change of plant height with increasing water stress in $\mathrm{Ra}$ 'ad $\times$ Monde combination was lower than others (Fig. 5C). In the scion of Super Chief onto Dashtestan rootstock as well as Ra'ad scion onto Mond rootstock, the plant height was not much influenced by drought stress levels. Many researchers have reported the reduction of plant height due to water deficit especially on tomato crops (Hale et al., 2005; Razmjoo et al., 2008; Maria, 2015).

Average fruit weight decreased when drought stress levels were intensified in all scion-rootstock combinations, however, the amount of this reduction varied in the graft combinations. Concerning the Dorahe rootstock, drought stress affected the fruit weight of Matine scion more than other scions onto this rootstock. The control of fruit weight influenced by drought stress was higher in Ra'ad scion onto Dorahe rootstock (Fig. 6A). In respect of Dashtestan rootstock, drought stress affected the fruit weight of all scions except the Matine. Control of fruit weight influenced by drought stress was higher in Matine scion onto Dashtestan rootstock (Fig. 6B). In the Mond rootstock, drought stress affected the fruit weight of Super Chief scion more than other scions onto the rootstock. The control of fruit weight influenced by drought stress was higher in Ra'ad scion onto Dorahe rootstock (Fig. 6C). In the scion of Ra'ad onto Dorahe and Mond rootstocks, the fruit weight did not show much response to drought stress levels. The findings reported by Hosseini and Nemati (2014); Dehghan et al. (2015); Mohammadi et al. (2011); Esmaeilpour and Akbari (2013) and Molavi et al. (2011) were in agreement with the results of the present study in the viewpoint of the reduction of fruit 
weight due to water deficit. Water deficit leads to a decrease in fruit weight by influencing the reduction of fruit juice.

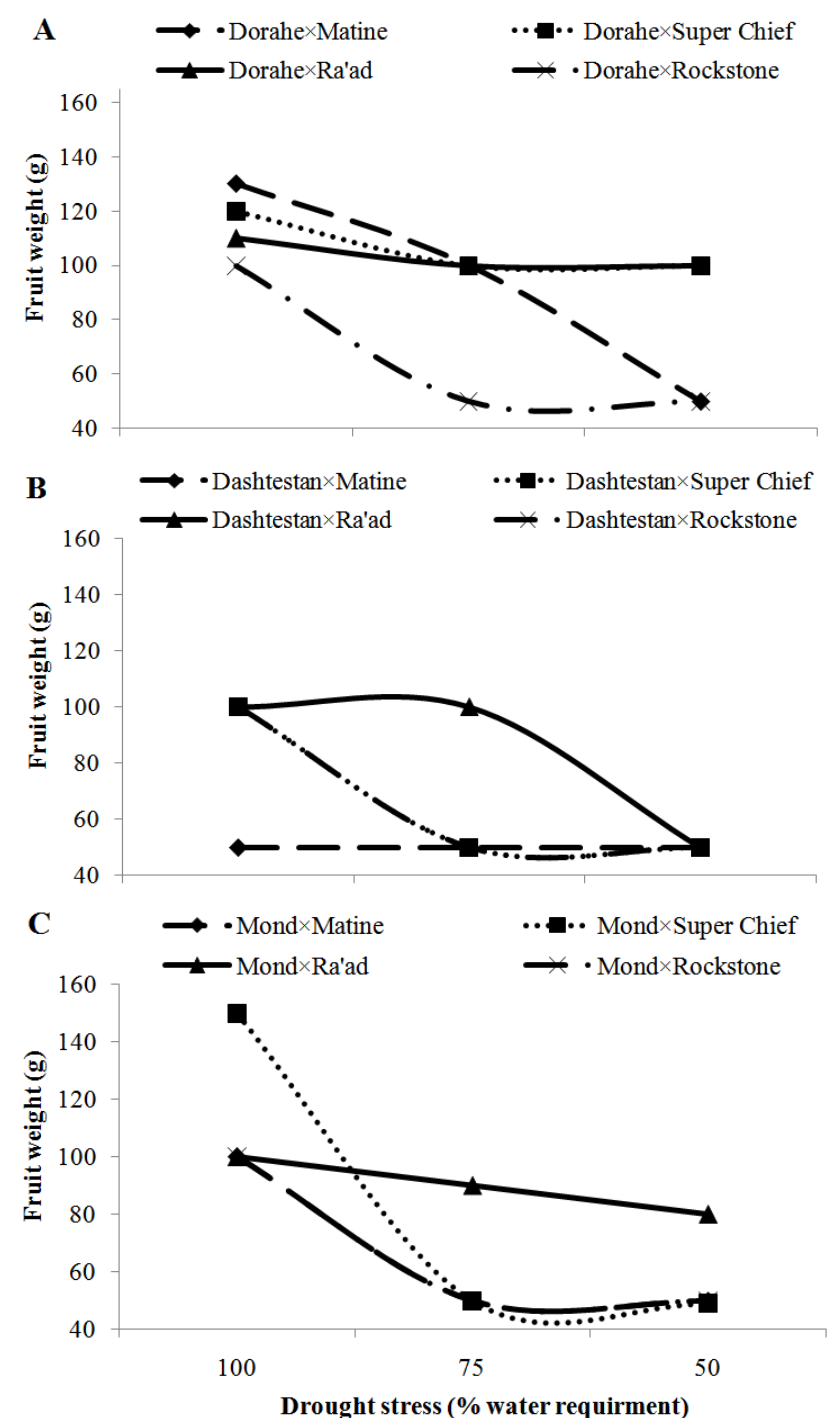

Figure-6. Fruit weight as influenced by interaction among drought strees, scion and each rootstocks of Dorahe (A), Dashtestan (B) and Mond (C)

Increasing the flower number affected by intensifying the drought stress levels was observed in all scionrootstock combinations. In Dorahe rootstock, the flower number was not much influenced by drought stress in the Rockstone scion. The highest change of flower number was observed in Super Chief, Matine and $\mathrm{Ra}$ 'ad scions onto Dorahe rootstock (Fig. 7A). In Dashtestan rootstock, drought stress affected the flower number of all scions, but this effect in Ra'ad scion was more than other scions onto Dashtestan rootstock (Fig. 7B).

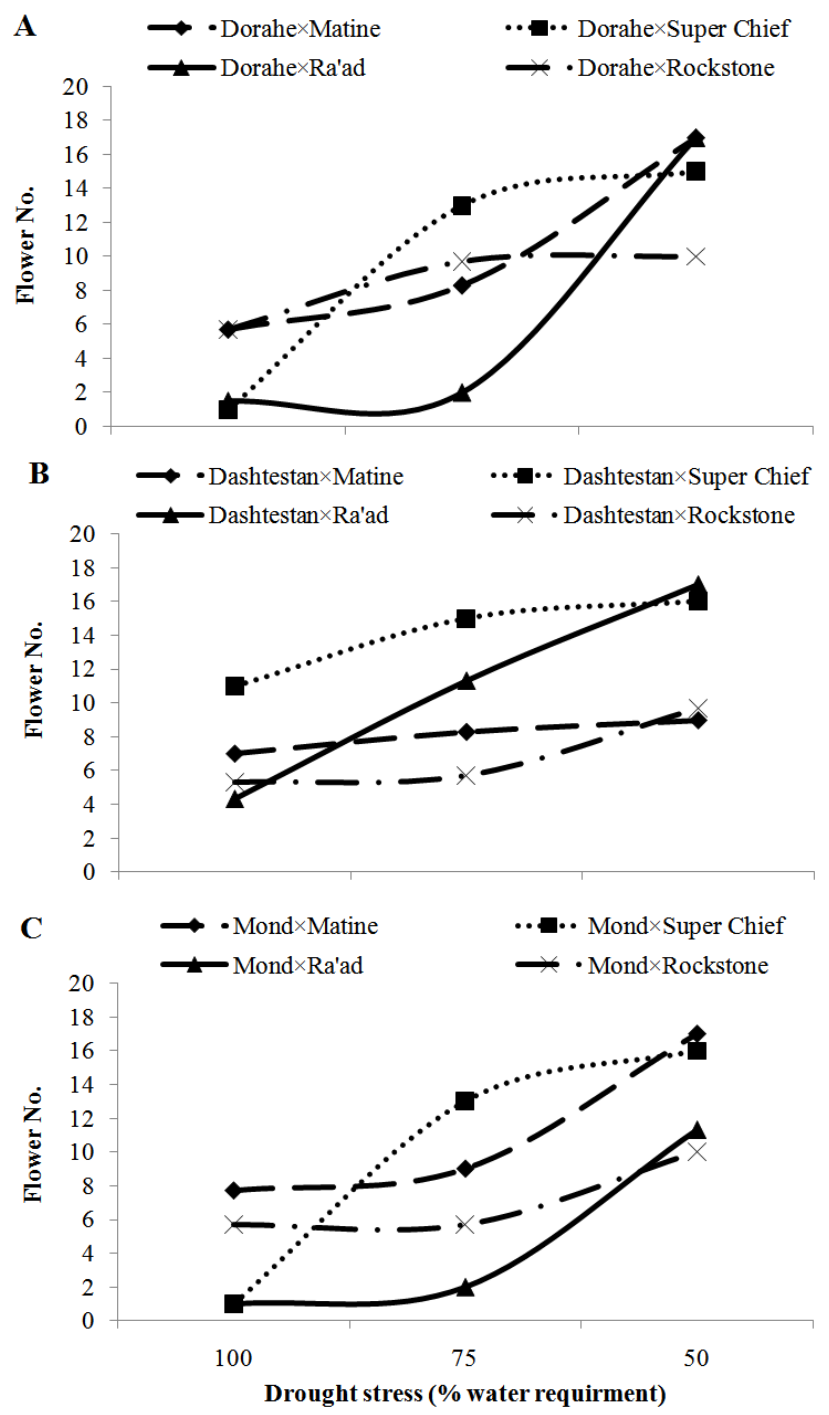

Figure-7. Flower number as influenced by interaction among drought strees, scion and each rootstocks of Dorahe (A), Dashtestan (B) and Mond (C)

In the Mond rootstock, change trends of flower number in all scions except Super Chief were the same so that increase of flower number from 100 to $75 \%$ water requirement was slow but from 75 to $50 \%$ water requirement was rapid. The lowest change in flower number was observed in Rockstone scion onto Mond rootstock (Fig. 7C). Generally, the flower number was not much influenced by drought stress levels in the scion of Matine onto Dashtestan rootstock. The findings reported by Hosseini and Nemati (2014) 
about tomato were similar to our study from the viewpoint of the enhancement of flower numbers due to water deficit. Decreasing the fruit number affected by drought stress levels was observed in all scionrootstock combinations. In this relation, Super Chief scion onto Dashtestan rootstock had the best status about fruit number under drought stress among other grafting combinations (Fig. 8A-C). Our results are following the findings reported by Hosseini and Nemati (2014) on tomato. Molavi et al. (2011) found that water deficit decreases the fruit number and yield of tomato. Tomato plants are susceptible to drought stress, so that water deficit causes a decrease in the vegetative growth and yield of tomato (Miguel and Francisco, 2007).

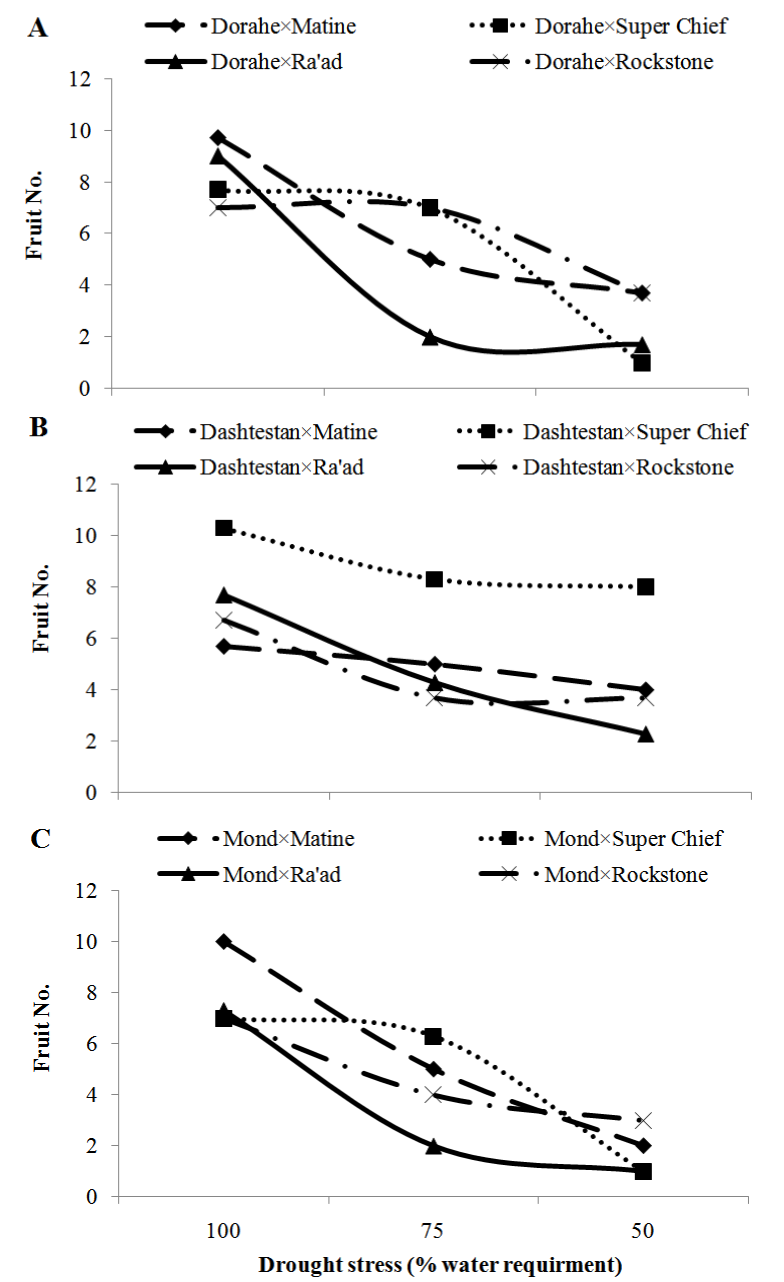

Figure-8. Fruit number as influenced by interaction among drought strees, scion and each rootstocks of Dorahe (A), Dashtestan (B) and Mond (C)

\section{Pigments and enzyme activities}

Generally, the amount of protein increased affected by intensifying the drought stress levels in all scionrootstock combinations, but this enhancement varied between the graft combinations. On the other hand, the changes in protein influenced by the drought stress were not very high. In Dorahe rootstock, the highest protein with the lowest change influenced by drought stress was recorded in the Rockstone scion (Fig. 9A).

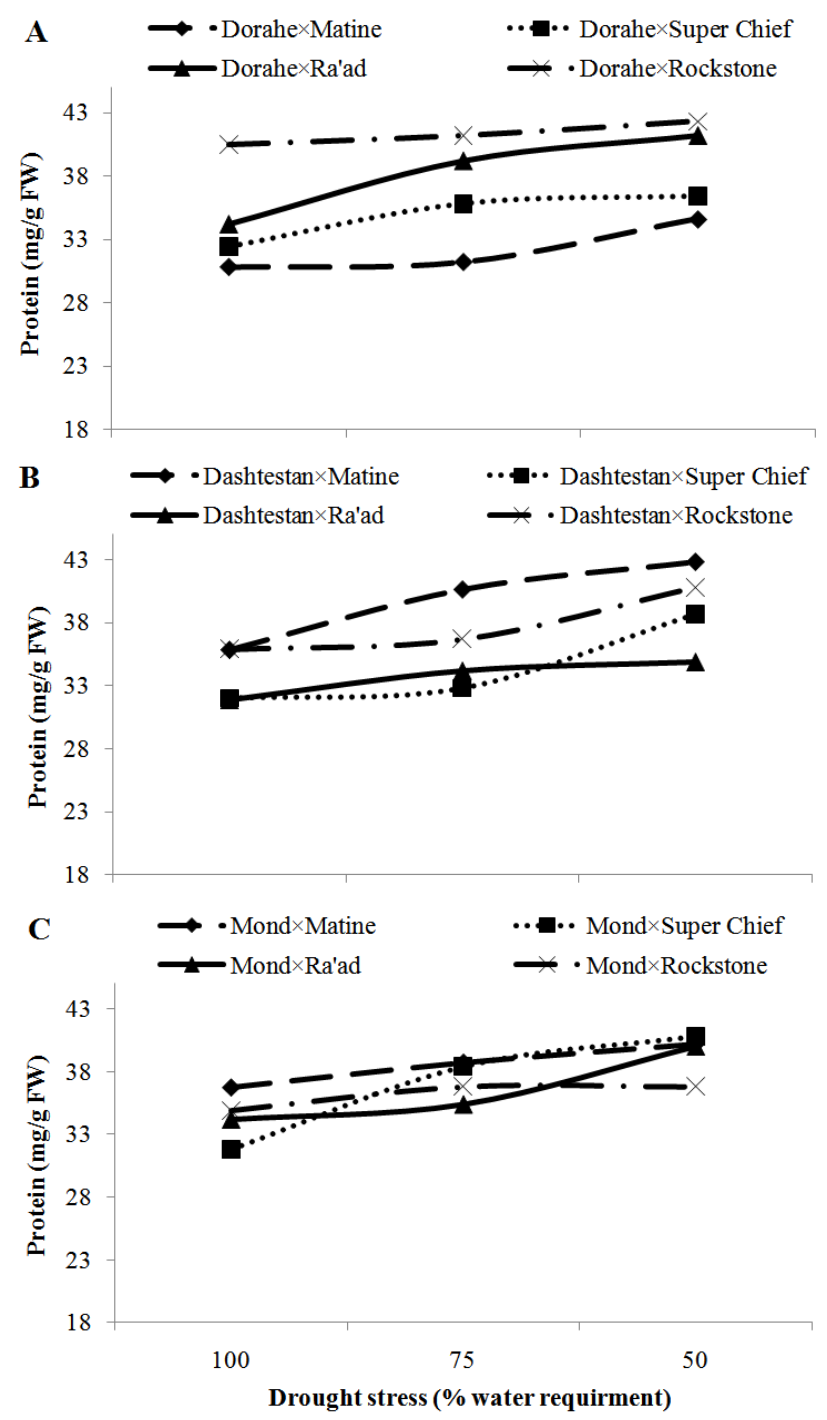

Figure-9. Protein content as influenced by interaction among drought strees, scion and each rootstocks of Dorahe (A), Dashtestan (B) and Mond (C)

In Dashtestan rootstock, the highest protein and the protein was not much influenced by drought stress in Matine and Ra'ad scions, respectively (Fig. 9B). In 
Mond rootstock, there was no difference among scions but the lowest protein change was observed in Rockstone scion compared to others (Fig. 9C). The reduction of lycopene affected by drought stress was observed in some scion-rootstock combinations (Fig.10A-C). The lowest lycopene reduction was recorded in Super Chief and Ra'ad scions onto Dashtestan rootstock (Fig. 10B). In the Mond rootstock, there was no significant difference among scions and they showed a uniform reduction of lycopene (Fig. 10C). Maria (2015) and Daneshmand (2014) reported that lycopene content decreased under water deficit, which is similar to our results.

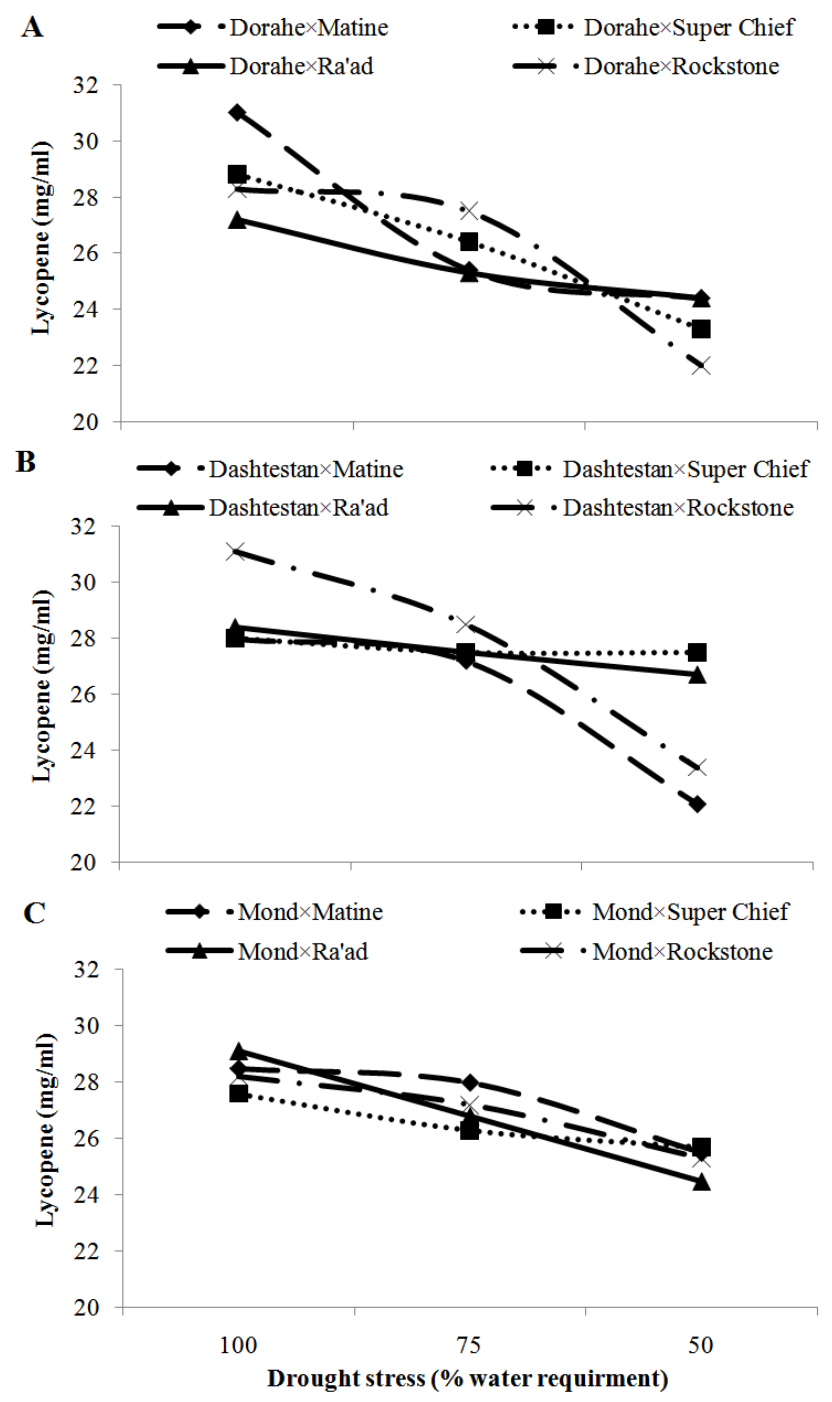

Figure-10. Lycopene content as influenced by interaction among drought strees, scion and each rootstocks of Dorahe (A), Dashtestan (B) and Mond (C)

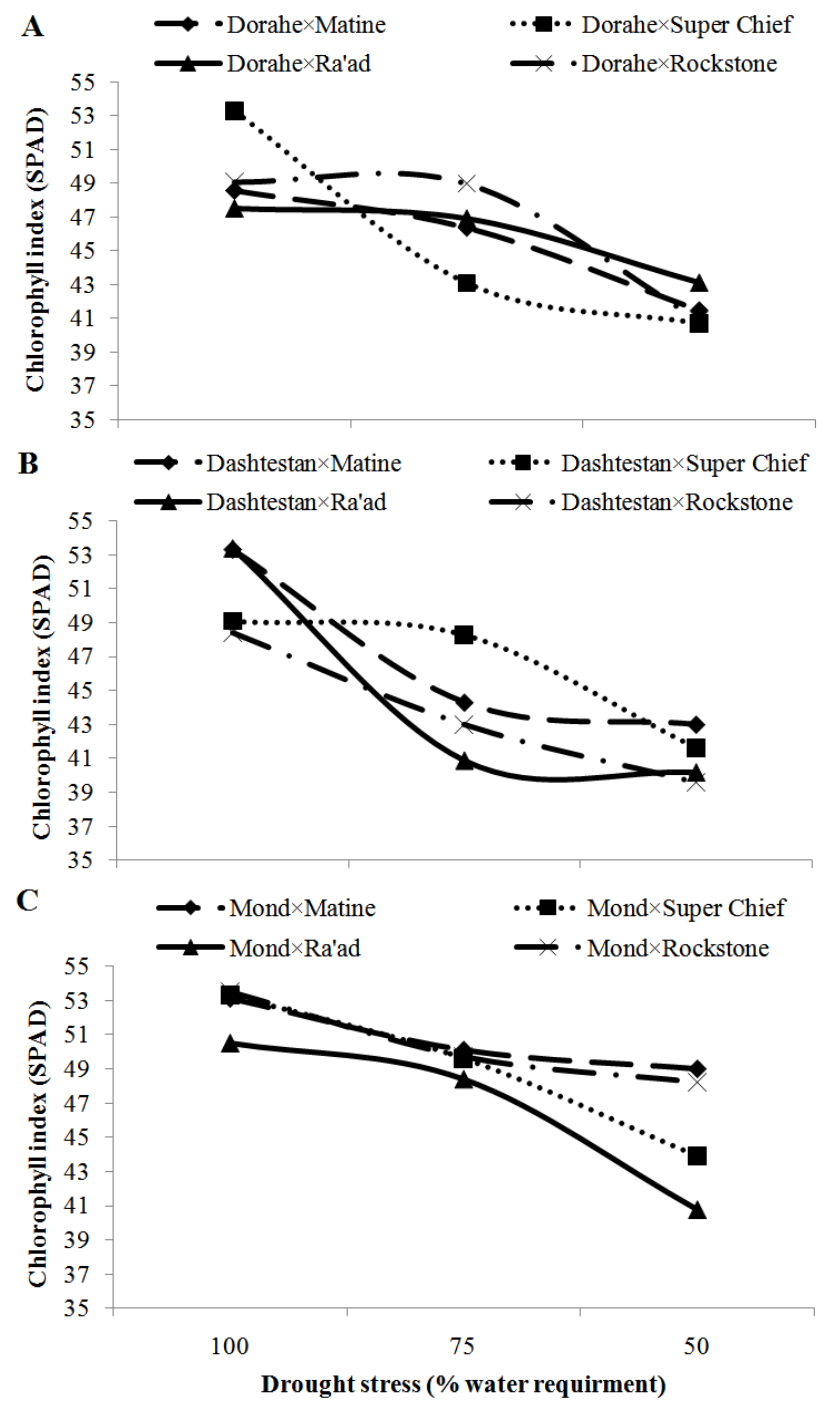

Figure-11. Chlorophyll index (SPAD) amount as influenced by interaction among drought strees, scion and each rootstocks of Dorahe (A), Dashtestan (B) and Mond (C)

\section{Chlorophyll and catalase (CAT) enzyme activity}

The amount of chlorophyll index decreased due to intensifying drought stress levels in all scionrootstock combinations, however, this enhancement varied among graft combinations. In the Dorahe rootstock, the highest reduction of chlorophyll index influenced by drought stress was recorded in Super Chief scion, so that reduction of chlorophyll index from 100 to $75 \%$ water requirement was higher than other scions onto Dorahe rootstock. The reduction of chlorophyll index from 75 to $50 \%$ water requirement was slower in Super Chief scion compared to other scions (Fig. 11A). In the Dashtestan rootstock, the change trends of chlorophyll index influenced by 
drought stress in Super Chief scions varied with other scions, so that chlorophyll index of this scion from 100 to $75 \%$ water requirement nearly was constant. In contrast, the chlorophyll index of the other three scions from 75 to $50 \%$ water requirement nearly was constant (Fig. 11B).

In the Mond rootstock, the amount of chlorophyll index of all scions decreased very low influenced by drought stress from 100 to $75 \%$ water requirement, however, in Super Chief and Ra'ad scions from 75 to $50 \%$ water requirement, decreasing the chlorophyll index was severe. In this relation, drought stress affected the chlorophyll index of two scions of Matine and Rockstone onto Mond rootstock lower than two scions of Super Chief and Rockstone (Fig. 11C).

About the activity of catalase, it increased after intensifying the drought stress levels in all scionrootstock combinations. In the Dorahe rootstock, the highest enhancement of CAT influenced by drought stress was recorded in Ra'ad scion, so that increasing of CAT in this scion-rootstock combination was linear (Fig. 12A).

In the Dashtestan rootstock, the highest enhancement of CAT influenced by drought stress was recorded in the Matine scion, so that increasing the CAT in this scion-rootstock combination was linear. The change trends of CAT in the other three scions were lower than the Matine scion (Fig. 12B). In the Mond rootstock, changes of CAT activity influenced by drought stress in all scions were lower than the other two rootstocks, while the highest CAT activity was observed in Ra' ad scion onto the Mond rootstock (Fig. 12C). Catalase disintegrates hydrogen peroxide to water and oxygen. Hydrogen peroxide is toxic for cells. Therefore, increasing the CAT activity in the plants under water deficit leads to tolerance against stress (Noctor and Foyer, 1998). Our results are similar to the findings reported by Daneshmand (2014).

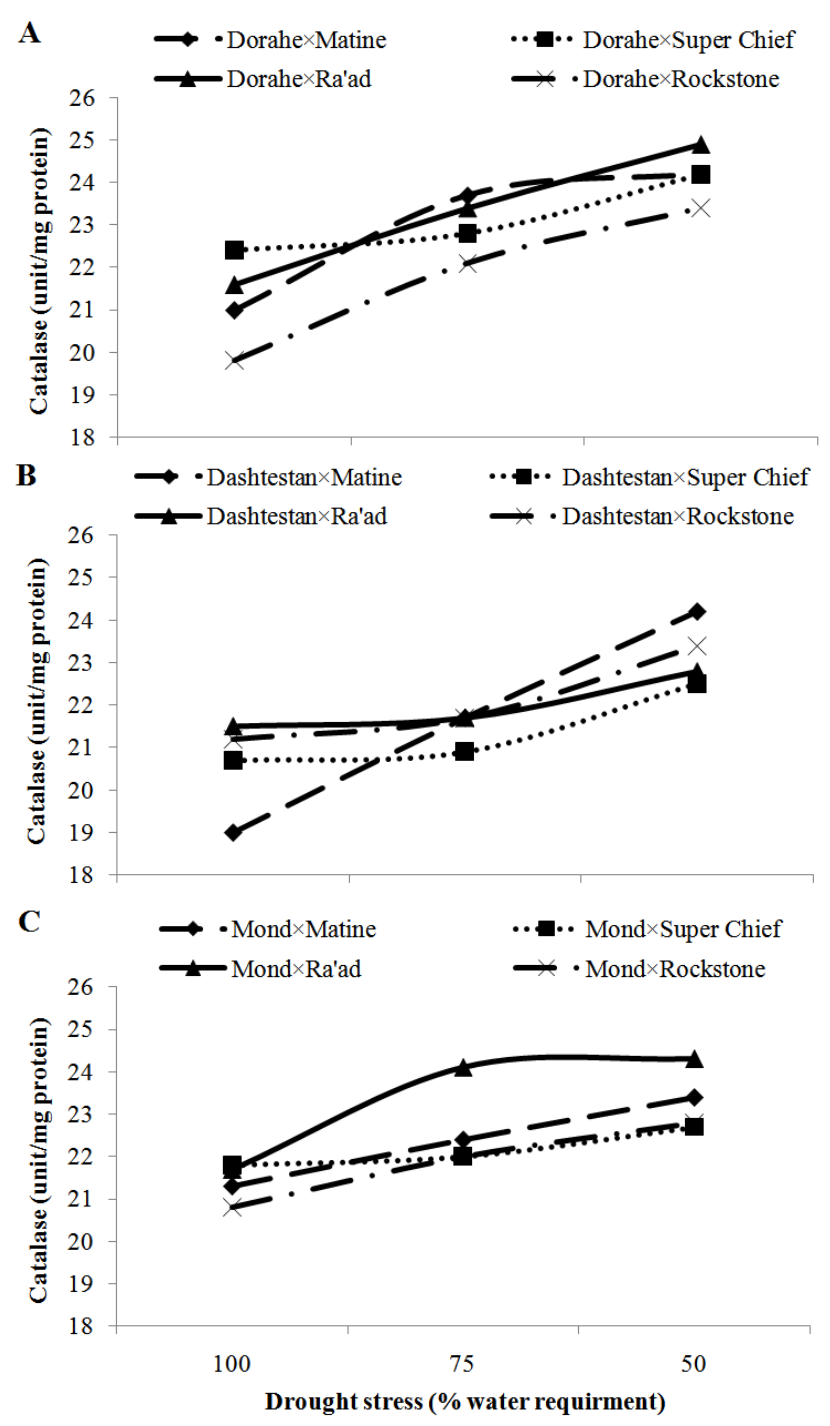

Figure-12. Catalase content as influenced by interaction among drought strees, scion and each rootstocks of Dorahe (A), Dashtestan (B) and Mond (C) 


\section{Peroxidase (POX) and super oxide dismutase (SOD) enzymes activity}

Concerning the peroxidase enzyme activity, it increased affected by intensifying the drought stress levels in all scion-rootstock combinations, however, in some cases, the activity of peroxidase had no change.

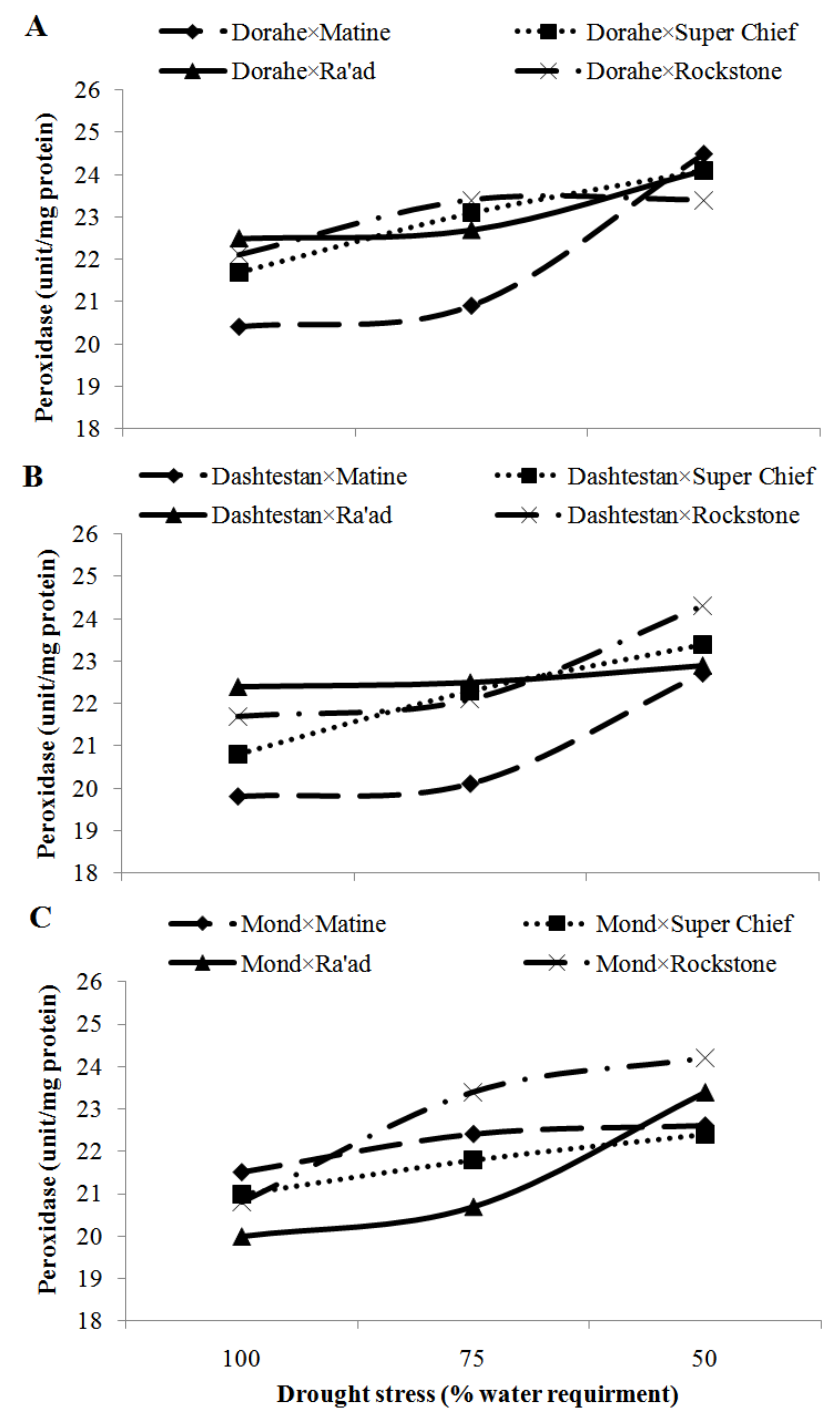

Figure-13. Peroxidase content as influenced by interaction among drought strees, scion and each rootstocks of Dorahe (A), Dashtestan (B) and Mond (C)

In the Dorahe rootstock, the final activity of peroxidase influenced by drought stress was equal in all scions, however, the activity of the enzyme had low enhancement in scions of Super chief, Ra'ad and Rockstone (Fig. 13A). In the Dashtestan rootstock, the highest change in peroxidase was observed in Matine scion and the activity of this enzyme in Ra'ad scion influenced by drought stress nearly was constant (Fig. 13B). In the Mond rootstock, the highest change in peroxidase was observed in Super Chief and Ra'ad scions (Fig. 13C). Generally, the lowest change in peroxidase activity was observed in the scions onto Dorahe rootstock compared to the other two rootstocks.

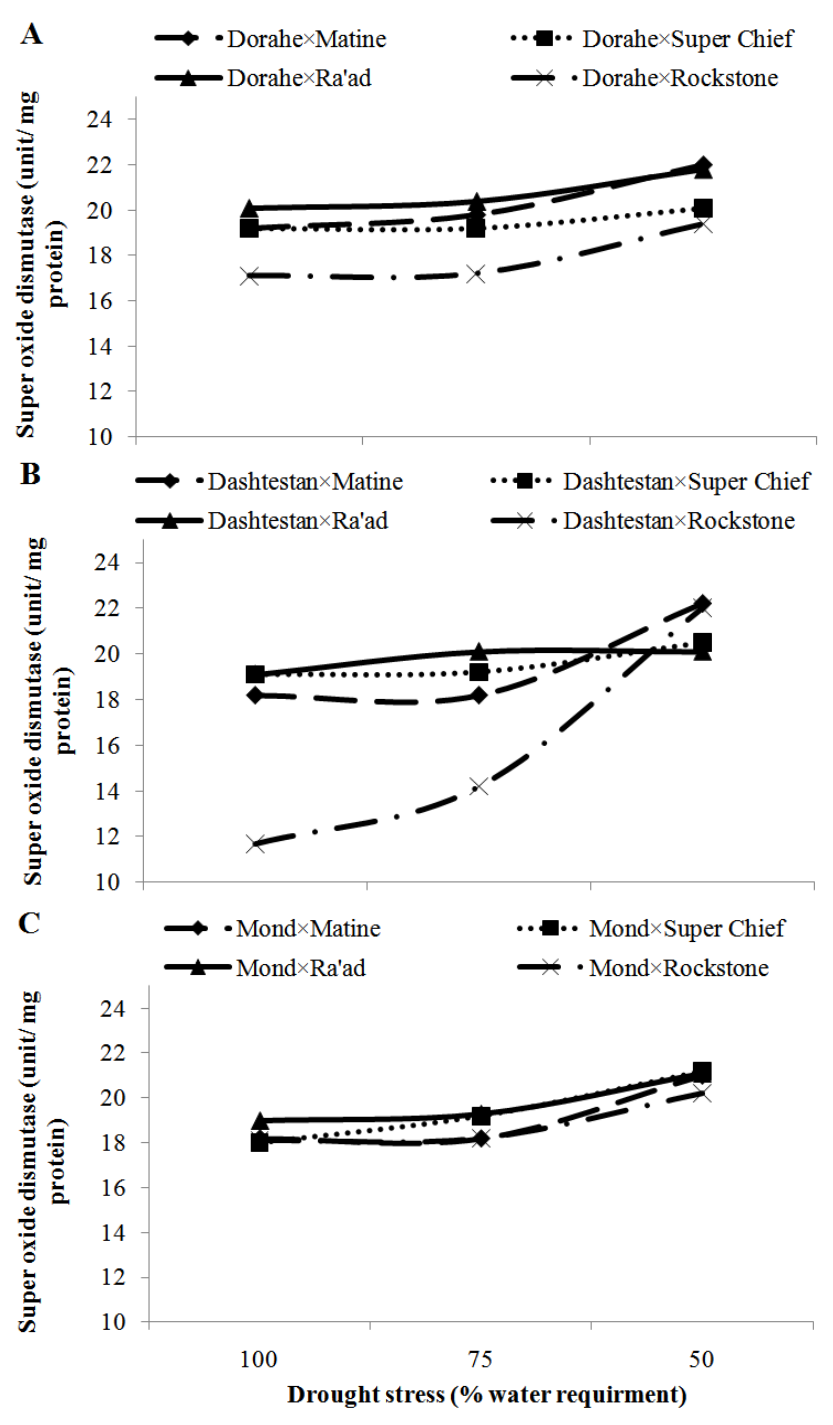

Figure-14. Super oxide dismutase content as influenced by interaction among drought strees, scion and each rootstocks of Dorahe (A), Dashtestan (B) and Mond (C)

The activity of SOD increased by intensifying the drought stress levels in all scion-rootstock combinations, however, in some cases, the activity of SOD had no change. Furthermore, the change of SOD 
activity influenced by drought stress was lower than the other enzymes in the study. In the Dorahe rootstock, the change of SOD activity influenced by drought stress was similar to all scions, whereas the lowest SOD activity was recorded in Rockstone scion (Fig. 14A). In the Dashtestan rootstock, the final amount of SOD activity influenced by drought stress was equal in all scions, however, the activity of this enzyme had low enhancement in scions of Matine, Super chief and Ra'ad (Fig. 14B). In the Mond rootstock, change of SOD activity in the scions was lower than other rootstocks, so that the enhancement of SOD activity influenced by drought stress was not severely (Fig. 14C). Increasing the activity of SOD occurs when the amount of superoxide ion increases in the cell (Smirnoff, 1996). It seems that during water deficit conditions, increasing the concentration of hydrogen peroxide derived from the activity of SOD causes promotion of CAT for the analysis of hydrogen peroxide. Daneshmand (2014) had a similar result on tomato plants to our findings.

\section{Conclusion}

In the viewpoint of rootstock and scion combination, the best combinations of rootstock and scion were Ra'ad and Super Chief scions, respectively onto Dashtestan rootstock for planting tomato under drought stress conditions. Therefore, in many of the evaluated parameters, these rootstock-scion combinations showed the best results.

Disclaimer: None.

Conflict of Interest: None.

Source of Funding: None.

\section{References}

Ashraf M and Harris PJC, 2005. Abiotic stresses: plant resistance through breeding and molecular approaches. The Haworth Press, New York. pp. 277-300.

Arnon AN, 1956. Method of extraction of cholorophyl in the plants. Agron. J. 23:112-121.

Agrawal R, MacMillan-Crow LA, Rafferty TM, Saba H, Roberts DW, Fifer EK, James LP and Hinson JA, 2011. Acetaminophen-induced hepatotoxicity in mice occurs with inhibition of activity and nitration of mitochondrial manganese superoxide dismutase. J. Pharmacol. Exp. Ther. 337:110-116.
Bradford MM, 1976. A rapid and sensitive method for quantitation of microgram of protein utilizing the principle of protein-dye binding. Anal. Biochem. 72:248-254.

Chachalis D, Khan EM, Kakava E, Mavromatisand A and Goulas C, 2006. Effect of grafting on growth and yield of tomato (Lycopersicon esculentum Mill.) in greenhouse and open-field. J. Appl. Hortic. 8:3-7.

Dehghan H, Alizadeh A, Esmaeili K and Nemati H, 2015. Root growth, yield and yield components of tomato (Solanum lycopersicum L.) in drought stress. J. Water Res. Agric. 29:170-179.

Dhindsa RS and Motowe W, 1981. Drought tolerance in two mosses: correlation with enzymatic defense against lipid peroxidation. J. Exp. Bot. 32:79-91.

Daneshmand F, 2014. The antioxidant defense system of the tomato plant responds to the tension of water and its removal with ascorbic acid. Plant Biol. 6:72-75.

Esmaeilpour B and Akbari M, 2013. Evaluation of irrigation effect on growth characteristics, yield and quality after harvest of two tomato (Solanum lycopersicum L.) varieties in Miandoab climate conditions. J. Agric. Ecol. 5:178-187.

Estan MT, Martinez-Rodriguez MM, Perez-Alfocea F, Flowers TJ and Bolarin MC, 2005. Grafting raises the salt tolerance of tomato through limiting the transport of sodium and chloride to the shoot. J. Exp. Bot. 56:703-712.

Fernandez-Garcia N, Martinez V, Cerda A and Carvajal M, 2002. Water and nutrient uptake of grafted tomato plant grown under saline conditions. J. Plant Physiol. 159:899-905.

Fish WW, Perkins-Veazie P and Collins JK, 2002. A quantitative assay for lycopene that utilizes reduced volumes of organic solvents. J, Food Composit. Anal. 15:309-317.

Guichard S, Bertin N, Leonardi C and Gary C, 2011. Tomato fruit quality in relation to water and carbon fluxes. Agronomie. 21:385-392.

Giannopolitis CN and Ries SK, 1997. Superoxide dismutase. I. occurrence in higher plants. Plant Physiol. 59:309-314.

Hosseini A and Nemati H, 2014. The effect of irrigation interval on growth characteristics, quantitative and qualitative yield of tomato (Solanum lycopersicum L.) in terms of application and non-use of plastic mulch. J. Agroecol. 6:552560. 
Hale BK, Herms DA, Hansen RC, Clausen TP and Arnold D, 2005. Effects of drought stress and nutrient availability on dry matter allocation, phenolic glycosides and rapid induced resistance of poplar to two lymantriid defoliators. J. Chem. Ecol. 31:2601-2620.

Matsuzoe N, Zushi K and Johjima T, 1998. Effect of soil water deficit on coloring and carotene formation in fruits of red, pink and yellow type cherry tomatoes. J. Japanese Soc. Hortic. Sci. 67:600-606.

Miguel A and Francisco M, 2007. Response of tomato plants to deficit irrigation under surface or subsurface drip irrigation. J. Appl. Hortic. 9:97100.

Maria R, 2015. Drought stress response in long storage tomatoes: morphological, physiological, yield and quality traits. Department of Agriculture, University of Naples Federico II.

Martin AW, Phyllis BM, Schroder FWR, Matsuo K and Li WB, 2002. Stabilization of cucurbitacine E-glycoside, a feeding stimulant for diabroticite beetles, extracted from bitter Hawkesbury watermelon. J. Insect Sci. 2.19.

Molavi H, Mohammadi M and Liyaghat E, 2011. The effect of full irrigation and one among the roots on performance, yield components and the efficiency of tomato juice consumption. J. Water Soil Sci. 21:15-126.

Mohammadi M, Molavi H and Liyaghat E, 2011. The effect of salinity and drought stress on yield and yield components of tomato in field conditions. J. Irrigat. Sci. Eng. 34:15-24.

Naotke M, Zushi K and Johjima T, 1998. Effect of soil water deficit on coloring and carotene formation in fruits of red, pink, and yellow type cherry tomatoes. J. Japanese Soc. Hortic. Sci. 67:600606.

Noctor G and Foyer CH, 1998. Ascorbate and glutathione: Keeping active oxygen under control. Annu. Rev. Plant Physiol. Plant Mol. Biol. 49:249-279.

Owen HR and Aung LH, 1990. Genotypic and chemical influenced on fruit growth of tomato. Hortic. Sci. 25:1255-1275.

Pouzesh-shirazi M, Bavaryani M, Modaresi M and Behzadi B, 2013. Effect of drought stress on vegetative and reproductive growth stages on quantity and quality of tomato product. Iranian J. Hortic. 44:451-459.

Razmjoo K, Heydarizadeh P and Sabzalian MR, 2008. Effect of salinity and drought stresses on growth parameters and essential oil content of Matricaria chamomile. Int. J. Agric. Biol. 10:451-454.

Plewa MJ, Smith SR and Wanger ED, 1991. Diethyl dithiocarbamate suppresses the plant activation of aromatic amines into mutagens by inhibiting tobacco cell peroxidase. Mutant Res. 247:57-64.

Riggi E, Patanè C and Ruberto G, 2008. Carotenoid content at different ripening stages in processing tomato in relation to soil water availability. Aust. J. Agric. Res. 59:348-353.

Smirnoff N, 1996. The function and metabolism of ascorbic acid in plants. Annals Bot. 78:661-669.

Sofo A, Bartolomeo DB, Xiloyannis C and Masia A, 2004. Effects of different irradiance levels on some antioxidant enzymes and on malondialdehyde content during rewatering in olive tree. Plant Sci. 166:293-302.

Shahabi M, 2011. The effect of different methods of grafting on the growth and yield of tomato cv. "Red Top". The First National Conference on Issues of Modern Electronic Horticultural Sciences, Horticultural Science Society of Jahrom University (p. 1-15). (In Persian)

Veit-Kohler U, Krumbein A and Kosegarten H, 1999. Effect of different water supply on plant growth and fruit quality of Lycopersicon esculentum. J. Plant Nutr. Soil Sci. 162:583-588.

Valantovic P, Luxova M, Kolarovi L and Gasparikora O, 2006. Effect of osmotic stress on compatible solutes content, membrane stability and water relation in two maize. Plant Soil Environ. 52:186191.

\section{Contribution of Authors}

Kazemi S: Contributed in design and conduct of research, analysis of variance and article write up Zakerin A: Contributed in editing and writing the article

Abdossi V: Contributed in editing and writing the article

Moradi P: Contributed in editing and writing the article 